\title{
FACTORIAL STRUCTURE OF PHYSICAL DEVELOPMENT AND PHYSICAL ABILITY OF STUDENTS
}

\author{
Nedyalka Mavrudieva, Dinara Zhunisbek, \\ Petko Mavrudiev, Milena Kuleva
}

\begin{abstract}
Introduction
The specific of the sports teacher work requires a good academic background and a certain level of physical fitness, sports and technical skills and movement culture. These facts underlie and provoke our interest in the presented issues.

Methodology

The Methodology of the survey is complex and includes: desk research of literature, teacher observation, testing, anthropometry, mathematical and statistical data processing and analysis. This survey was conducted during the academic year 2015/16.

Objective of the study is detecting the factorial structure of physical development and physical ability of students, IV year in the NSA "Vassil Levski" - Sofia.

Subject of the study are the signs of physical development and physical ability of students.

Target group of the study: 48 students, IV year, Coaches' faculty and Teachers' faculty of the NSA.

For the purpose of the study, a 9 indicators testing of students was conducted, carrying information about main signs of physical development and physical ability.

The results from the study have been processed by variation and factor analysis.

Results

Three main factors that characterize the specifics of the surveyed targeted group, have been outlined, which are explaining the total percentage of the starting dispersion of the studied process (67, 08\%).

\section{Discussion and conclusions}

The most important for the studied population students is the morphological factor, which shows high importance of: weight-lifting parameters and strength of upper limbs.

On second place about the importance of physical fitness by the studied population are: speeding and speed-power capabilities of the lower limbs.

On third place are: the speed-force abilities of abdominal and spinal muscles.
\end{abstract}

Key words: students, factorial structure, physical development, physical ability

\section{Introduction}

It is well known that the professional realization of the sports pedagogue is based on good academic training and the pursuit and motivation for continuous improvement. The specific of the sports teacher work requires a good academic background and a certain level of physical fitness, sports and technical skills and movement culture. These facts underlie and provoke our interest in the presented issues.

In a very interested publication by Harvard Business Review is presented the High-Performance Pyramid. (Loehr, Schwartz, 2001) According to the publication, the maximum productivity and high performance on the work place is possible, when four factors are combined together - physical well-being (resistance to stress), emotional balance, mental capacity and motivation. However, the basis of the pyramid is not any, but the physical capacity, in our opinion, which is significant for sports pedagogues also.

This fact, and also similar publications in this area (Borukova, 2015; Borukova, 2014; Iskrov, 2015; Mavrudieva, 2008; Hristova, 2015) provoke our interest in the presented issue.

\section{Methodology}

The Methodology of the survey is complex and includes: desk research of literature, teacher observation, testing, anthropometry, mathematical and statistical data processing and analysis. This survey 
was conducted during the academic year 2015/16.

Objective of the study is detecting the factorial structure of physical development and physical ability of students, IV year in the NSA "Vassil Levski" - Sofia.

Subject of the study are the signs of physical development and physical ability of students.

Target group of the study: 48 students, IV year, Coaches' faculty and Teachers' faculty of the NSA.

For the purpose of the study, a 9 indicators testing of students was conducted, carrying information about main signs of physical development and physical ability.

The results from the study have been processed by variation and factor analysis.

\section{Results}

The results of the variance analysis of the observed physical development and physical capacity indicators (table 1 and fig. 1) show that the values have a normal distribution for most of the indicators, only in the indicator related to the abdominal muscularity, the distribution is different from the normal. The observed population is homogeneous in terms of the height (V1=3.36\%), the degree of obesity (V3 $=8.95 \%)$, the speed capability of the students $(\mathrm{V} 4=7.37 \%)$ and their speed-power capabilities (V8=7.18\%). The examined population is relatively homogeneous in terms of weight, blast strength of lower limbs (V5=11,99\%) and strength of upper limbs $(\mathrm{V} 6=18,90 \%)$ and $(\mathrm{V} 7=21,65 \%)$. Abdominal muscles $(\mathrm{V} 9=0.97 \%)$. Three main factors that characterize the specifics of the surveyed targeted group, have been outlined, which are explaining the total percentage of the starting dispersion of the studied process (67, 08\%), (table. 2).

Table 1

Average values and variability of the surveyed indicators

\begin{tabular}{|l|l|l|l|l|l|l|l|l|l||}
\hline № & Indicators & $\mathrm{N}$ & Min. & Max. & $\mathrm{X}$ & $\mathrm{S}$ & $\mathrm{As}$ & $\mathrm{Ex}$ & $\mathrm{V} \%$ \\
\hline 1. & Height & 48 & 1,68 & 1,93 & 1,81 & 0,060 & $-0,223$ & $-0,664$ & 3,36 \\
\hline 2. & Body mass & 48 & 57,00 & 102,00 & 77,92 & 9,118 & 0,189 & 0,699 & 11,70 \\
\hline 3. & BMI & 48 & 18,11 & 29,48 & 23,86 & 2,130 & $-0,207$ & 1,729 & 8,95 \\
\hline 4. & Run $20 \mathrm{~m}$ & 48 & 4,20 & 3,00 & 3,55 & 0,261 & 0,351 & 0,163 & 7,37 \\
\hline 5. & Long jump from positon & 48 & 1,80 & 3,35 & 2,31 & 0,277 & 0,773 & 2,939 & 11,99 \\
\hline 6. & $\begin{array}{l}\text { Throwing a solid ball of } \\
\text { leg }\end{array}$ & 48 & 4,13 & 10,00 & 6,90 & 1,305 & 0,461 & 0,1 & 18,90 \\
\hline 7. & $\begin{array}{l}\text { Throwing a solid ball } \\
\text { from seating }\end{array}$ & 48 & 2,5 & 13,00 & 9,39 & 2,032 & $-0,816$ & 1,814 & 21,65 \\
\hline 8. & Running 10x5 m & 48 & 13,71 & 19,56 & 16,51 & 1,184 & 0,593 & 0,812 & 7,18 \\
\hline 9. & Crunches & 48 & 15 & 58 & 28,48 & 8,819 & 1,898 & 4,083 & 30,97 \\
\hline
\end{tabular}

Table 2

Factor structure of the physical development and physical capacity of students of IV year - Coaching faculty and Teachers faculty at NSA

\begin{tabular}{|l|l|l|l|l|l|l|}
\hline № & Indicators & I & II & III & $\mathrm{h}^{2}$ & $1-\mathrm{h}^{2}$ \\
\hline 1. & Height & $\mathbf{0 , 7 5 3}$ & $-0,138$ & $-0,350$ & 0,786 & 0,214 \\
\hline 2. & Body mass & $\mathbf{0 , 9 0 9}$ & 0,055 & 0,278 & 0,708 & 0,292 \\
\hline 3. & BMI & $\mathbf{0 , 6 1 8}$ & 0,147 & 0,614 & 0,906 & 0,094 \\
\hline 4. & Run 20 m & 0,090 & $\mathbf{0 , 6 8 4}$ & $-0,387$ & 0,625 & 0,375 \\
\hline 5. & Long jump from positon & 0,097 & $\mathbf{- 0 , 8 1 3}$ & 0,060 & 0,675 & 0,325 \\
\hline 6. & Throwing a solid ball of leg & $\mathbf{0 , 7 6 0}$ & 0,036 & $-0,063$ & 0,582 & 0,418 \\
\hline 7. & Throwing a solid ball of seating & $\mathbf{0 , 7 2 2}$ & $-0,266$ & 0,186 & 0,627 & 0,373 \\
\hline 8. & Running 10x5 m & $-0,077$ & 0,722 & 0,140 & 0,547 & 0,453 \\
\hline 9. & Crunches & $-0,004$ & $-0,124$ & $\mathbf{0 , 7 5 2}$ & 0,581 & 0,419 \\
\hline $\begin{array}{l}\sum \mathrm{a}^{2}= \\
67,08 \%\end{array}$ & & $33,87 \%$ & $19,78 \%$ & $13,49 \%$ & & \\
\hline
\end{tabular}




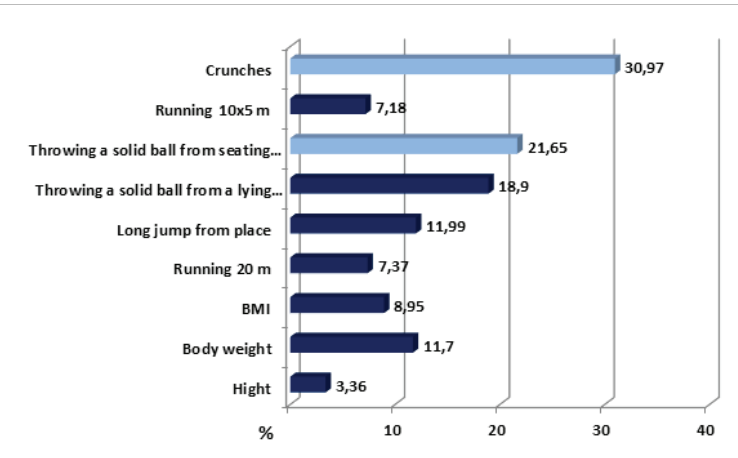

Fig. 1. Variance coefficient (V\%)

In addition to the factor weights, the table also presents data on the magnitude of the explained $\left(h^{2}\right)$ and the unexplained $\left(1-h^{2}\right)$ source dispersion of each studied sign. The analysis of table 2 shows that the first deduced factor explains $33.87 \%$ of the initial dispersion of the study phenomenon. The following two have a lower contribution to the overall physical development and specific ability of students (19.78\% and $13.49 \%$ respectively).

The first factor in the factor structure of the physical development and physical capacity of the 4th year students in the NSA is determined by five main indicators and, as already noted, explains the highest percentage of the initial dispersion of the phenomenon under investigation (33.87\%). This factor can be defined as morphological, because it reveals the place in the factor structure of indicators related to the height-to-weight ratios. They are also a prerequisite for the higher achievements in throwing a solid ball, both from leg and seating. (fig. 2).

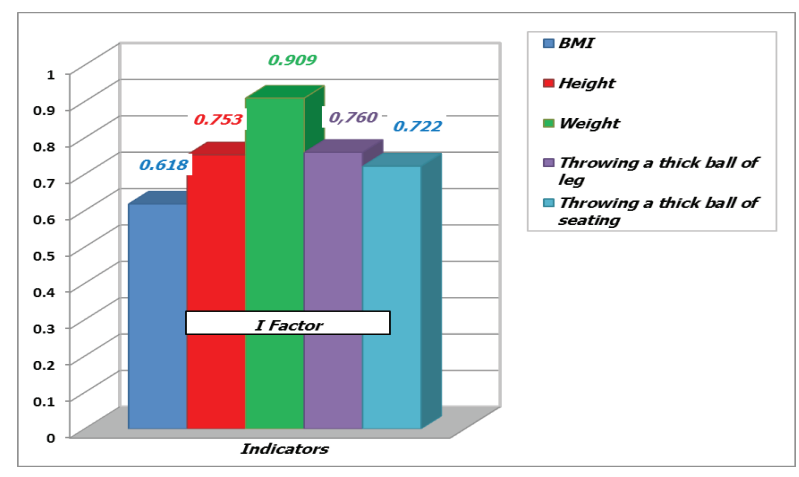

Fig. 2. Factor structure of the physical development and physical capacity of students of IV course at NSA

The second factor in the factor structure of physical development and physical capacity of students is determined by three main indicators, which explain a high percentage of the initial dispersion of the phenomenon under study (19.78\%). The indi- cators that determine this factor are related to the students' physical training. In the study, the excellent speed and speed-power capabilities are a prerequisite for higher achievements in $20 \mathrm{~m}$ running, $10 \times 5 \mathrm{~m}$ running and 2-leg-length jump from position. (fig. 3).

The third factor in the factor structure of the physical development and physical capacity of the students is determined by one indicator which, however, explains a high percentage $-13,49 \%$ of the initial dispersion of the phenomenon studied. This is the indicator of the speed-power abilities of abdominal and spinal muscles.

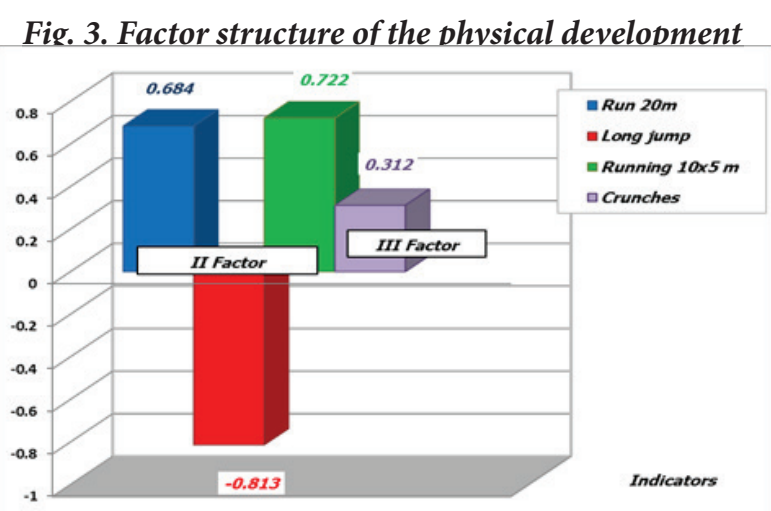

and physical capacity of students of IV course at NSA

\section{Conclusions}

An analysis of the results regarding the factor structure of the physical development and the physical capacity of the IV course students at NSA gives us the reasons to formulate the following conclusions:

The most important for the studied population students is the morphological factor, which shows high importance of: height-weight parameters and strength of upper limbs.

On second place about the importance of physical fitness by the studied population are: speeding and speed-power capabilities of the lower limbs.

On third place are: the speed-force abilities of abdominal and spinal muscles.

\section{References:}

Borukova M. Ivanov. I, Izsledvane dulgosrochnata motivacia na studentite ot NSA. Soia, Sport \& Science, 5/2015, 63-68 // Борукова, М., Иванов, И., Изследване дългосрочната мотивация на студентите от НСА, София, Sport \& Science, 5/2015, 63-68 
Borukova M. „Factor structure and basic factors of the physical development and the specific workability of growing up basketball players $\left(12-19\right.$ years old) ".- $9^{\text {th }}$ FIEP European Congress - Physical Education and Sport - Completence for life 9-12 October 2014. Proceeding book, p.287-296.

Gigova V. Statisticheska obrabotka I analiz na danni. Sofia, NSA pres. 1999, 42-46. // Гигова, В., Статистическа обработка и анализ на данни, София, НСА прес, 1999, 42-46

Iskrov V. Lidersko povedenie na treniora I vrazkata mu sas sportnoto postijenie, Sofia. Sport \& Science, 5/2015, 159-164 // Искров, В., Лидерското поведение на треньора и връзката му със спортното постижение, София, Sport\&Science, 5/2015, 159-164

Mavrudieva N. Faktorna struktura na fizicheskata god- nost I sportno-tehnicheskite umenia na uchenici ot VI klas na SOU. Sport I nauka, izvanreden broi 4/2008, s. 173-183. // Маврудиева, Н., Факторна структура на физическата годност и спортно-техническите умения на ученици от VI клас на СОУ. В “Спорт и наука”. Извънр. Брой 4/2008, с. 173-183.

Hristova V. Izsledvane na motivacionnata aktivnost na studentite ot NSA "V. Levski" specialnost "Kinesiterapia" kum uchebnata disciplina sitting volleyball. Sofia, Sport \& Science, 5/2015, 164-169. // Христова, B., Изследване на мотивационната активност на студентите от НСА “В. Левски” специалност „Кинезитерапия“ към учебната дисциплина siting volleyball, София, Sport\&science, 5/2015, 164-169.

Jim Loehr \& Tony Schwartz, The Making of a Corporate Athlete, Harvard Business Review, https://hbr. org/2001/01/the-making-of-a-corporate-athlete 